\title{
„Caution, Herr Buback! \\ The Attorney General in the Mist of the Interests of the Four Powers
}

\author{
Artur Braun
}

The assassination of Federal Attorney General Siegfried Buback as chief prosecutor of the Federal Republic of Germany in April 1977 was phenomenologically a successful frontal strike against the West German state. Even today, members of the Red Army Faction claim credit for this assassination as a success of the resistance against the Federal Republic, which with military precision and at equal level had plunged the state power into a national crisis. Buback played a noticeable role in the East-West conflict of the 60s and 70s as a federal prosecutor. With the departure of the era of détente, he was appointed attorney general and became the protagonist of the fight against terrorism. The so-called "Kissinger Cables", classified diplomatic correspondence of the US State Department from the years 1973-1976, provide a glimpse on what turmoil the Federal Attorney General created for the Allies and the German government until shortly before his assassination. The purpose of this manuscript is to analyze Buback's action during the East-West conflict of the 60s and 70s and to come to a view of the same from the diplomatic point of view of the Allies and the Federal Government.

Keywords: red army faction; East-West conflict; cold war; Buback; terrorism; 


\section{Case finally closed 38 years after the assassination}

In Spring 2015, Attorney General (AG) Mr. Harald Range at the Federal Court of Justice of Germany closed the investigation case against seven members of the Red Army Faction (RAF, Rote Armee Fraktion) about the assassinations of former Attorney General (Generalbundesanwalt) Siegfried Buback, his driver Wolfgang Göbel and Georg Wurster, another member of the driver staff (Pedersen 2015).

Decisive for the closing of the investigation was, according to the AG, that all the defendants had already served long prison sentences for membership-related offenses.

Public will likely never know (Greven 2012) who killed the AG and his two companions in a brutal act of terror in Karlsruhe on the $7^{\text {th }}$ of April 1977.

Buback and his companions, waiting at a red traffic light on their way to the AG's office, were then murdered by two assailants on a motorbike, who used a HK33 assault rifle to kill the three men with rounds of shots of the NATO calibre 0.223 inch.

Even if we knew the name of the assassin who had pulled the trigger of the rifle, it would be interesting to know who, to put it symbolically, had pointed to gun on the AG. This resembles the question about „horse and rider", which not only from the criminological perspective is of prime interest. This question has not been posed publically, because its bizarr answer had been revealed and circulated as a secret message among terrorists, as we will learn later in this paper.

Legally and therefore "State-wise", the terrorist attack seems sufficiently elucidated. Whereas the finding of the Truth before the Courts was not so successful. Günter Sonnenberg, Rolf Heisler und Christian Klar - three male terrorists - were officially identified as offenders, accused and sentenced.

However, still on the morning of the terror attack at around 09:30 am, minutes only after the assassination from the motor bike, a five minute radio interview was aired in which Ulf Stuberger, radio correspondent for the German Südwestrundfunk SWR (Schmid 2014) reported statements from eyewitnesses that ,... and there was a female on the pillion“.

It is thus remarkable with what certainty German judiciary and police hold on to the suggestion that the two perpetrators on the motorcycle were males.

A female as accomplice can be ruled out (Leyendecker 2010), were the unanimous statements of those who prepared the prosecution. This was in contradiction to statements by eyewitnesses who claimed that the shooter on the pillion was a petite woman.

In the year 2008, Professor Dr. Michael Buback, son of the slain AG, learnt about the involvement of female terrorist Verena Becker in the assassination of his father (taz 2008). Becker had been sentenced in the early 1970s as an accomplice in the slaying of another man (Buback 2009). Michael Buback therefore rallied for a new court trial against Becker, in which she was sentenced in the year 2012 to four years prison because of her complicity in the RAF (OLG 2012). But to the disappointment of the son of the slain, who was co-plaintiff in the new trial, Becker's individual contribution in the murder of the AG was not clarified. Michael Buback criticized the Court, Attorney General's Office and Police for negligance in the investigation and pleaded in his statement as co-plaintiff in 2012 for fair justice: „Offender and deed have to match“ (Buback 2012).

German Federal Secretary of Interior Werner Maihofer is quoted with „In the foreground is always the deed", where he justified the objectivity of trials of terrorists against any suggestion of political justice in Germany (Croissant 1976), although the actual accusation and deed could not be proofed 
in various trials. It was because of this unsatisfactory situation, that the accusation of an actual criminal deed in the criminal code was replaced by the accusation of being member of a criminal or terrorist organization. This has been implemented in the German criminal code with $\S 129$ and $\S 129$ a Strafgesetzbuch (Diewald-Kerkmann 2005).

The assassination of Buback was primarily investigated with view on the assailants in the RAF, who were ultimately not all personally identified with their individual criminal contributions.

Since the sentenced convicts Klar, Sonnenberg, and Wischnewski and their accomplice Becker have not made a confession, there rests a principal final doubt on their individual guilt about the assassination of AG Buback and his companions.

Verena Becker said in her statement at her trial in 2012 (Friedrichsen 2012): "You want to know who killed your father. I cannot answer you this question. Because I was not there."

Whether Verena Becker told the truth at court or not, remains open. As an accused at court she is allowed to remain silent. She is allowed to tell a lie. Certainly it is of utmost importance for the case, if she told the truth or not. What we know for sure is - the assassination was carried out with the precision and professionalism of a military command, for which only few people are physically and mentally capable (Andrawes Sayeh 1995).

The motor bike which was used by the driver and the killer was a new model Suzuki 750 GS. Only few months before the terror act it was available on the German market. It was the fastest commercially available motor bike of its time back then in 1977. It is a bizarre side note that the advertising campaign by Suzuki Deutschland announced the Suzuki 750 GS as ,Sports gun for snipers“ („Sportskanone für Scharfschützen“). This was not a cynical abuse of the attack by Suzuki Deutschland. Rather, exactly this promotion slogan had been prepared weeks before the attack (Deutscher Werberat, 1977).

Mastering this kind of racing motor bike under "combat conditions" requires a long and deep sportive preparation, which requires also an appropriate technical infrastructure. Werner Sonnenberg had leased this motor bike only days before the attack. There are hints that a second motorbike was around during Buback's assassination. It would be a strange hypothesis that a second such Suzuki 750 GS or similar would have been used for the attack (Klöckner 2012), maybe by actors without trace. There are indeed hints which point to a second motor bike, for example a set of Suzuki screwdrivers, one of which was found on Verena Becker and Werner Sonneberg after their bloody arrest in Germany in $3^{\text {rd }}$ May 1977. Therefore, from the forensic point of view, final conclusion about the involvement of actors is stained with doubt.

During trial in 2012, co-plaintiff Michael Buback presented numerous contradictions in the chain of reasoning of the $\mathrm{AG}$, which were by the court neither considered nor clarified. In lieu of clarity, court settled for conviction, on which it based its verdict against Becker as accomplice.

Because of these difficulties with the identity of the assailants and convicts and accused, not to mention the potential actors who pulled strings behind the curtain, it is appropriate to look closer into the role of the slain Attorney General Buback, particularly into his role as Investigator for the Attorney General's Office and his function for the State in general. 


\section{Career and work of Siegfried Buback}

Siegfried Buback was in his capacity as Federal Attorney (FA) and later as highest rank investigator and prosecutor, Attorney General (AG) of the Federal Republic of Germany (FRG) very successful and held the esteem of a hard fighter with a strong drive for enforcement (Schmidt 1977). Possibly it was this claim for fame which eventually took his life. With the same ambitiousness as AG Buback conducted his investigations and prosecutions in office, his son, chemistry Professor Dr. Michael Buback, followed his personal mission of finding the true murderer of his father and his companions (Buback 2009). A human driven mission which fell in major parts of the general population in German on fertile ground. Father and son had in common that they were both relentless and persistent in their mission, which attracted a public attention frequently more on their personality than on their original mission.

Although not present in the public memory, Siegfried Buback's name is closely linked with a number of scandals and state crises in the 1960s and 1970s. In the most risky year of the cold war between east and west, in 1962, the freedom of the press in Germany was at stake. The German "Der Spiegel", a political magazine and government critical tabloid, had published an article about a NATO maneouvre and concluded on NATO's limited ability to defend the FRG (Ahlers 1962)

. German Minister of Defense, Franz-Josef Strauss, suspected a mole in his Department who had leaked secret information to the press. The Spiegel publishing house in Hamburg was searched, and publisher Rudolf Augstein and all his editors were arrested. Over night, the Spiegel scandal (Spiegel-Affäre) made it in the news world wide.

Conrad Ahlers, who had authored the infamous Spiegel article with title "Bedingt abwehrbereit" (limited preparedness for defense), could not be arrested during the raid in the Spiegelhaus in Hamburg because he was on vacation in Spain. And Rudolf Augstein was at a location unknown to the police. In order to give the police in Spain a reason for Ahlers' arrest, Defense Minister Strauss sexed up the supposed spy case and had his Military Attachee Colonel Oster (Spiegel 1965) say that Publisher Augstein had already fled Germany in a Russian submarine, heading for Cuba. Because of the German foul play with Ahler's arrest in Dictator's Franco Spain, public outcry went across the globe, and Strauss had to resign from Office.

It had shed a bad light on the still young, juvenile German democracy that its police and justice were raiding the central office of a major political press tabloid and arresting journalists by numbers in order to find an information leak, a suspected mole in the German military force. To many people this was an attack on the free press.

It was Federal Attorney (FA) Siegfried Buback in this case of claimed treason who was the principle investigator for the Attorney General. Buback and the State Secretary of Interior in Hamburg (and later German Chancellor from 1974-1982) Helmut Schmidt were facing each other for the first time on 27. October 1962 at the Hamburg Police Headquarters. This was the day following the raid at the Spiegelhaus and the arrest of its protagonists.

This Spiegel scandal, in which First Federal Attorney Siegfried Buback was investigating for treason, even against the Hamburg Secretary of Interior Helmut Schmidt, a social democrat (Spiegel 2012a, Spiegel 2012b), turned into a serious crisis for the christian democrat cabinet of Chancellor 
Konrad Adenauer. Helmut Schmidt had 8 months before successfully fought a dangerous flood catastrophe and likely saved the lives of tens of thousands of people on the German coast by calling out an emergency state and demanding the German military to aid with their soldiers and resources - an unconstitutional move and illegal decision for which he still holds a bipartisan heroic status in the German population. During the Spiegel state crisis, more bizarre scenes happened. For example, Konrad Adenauer had ordered his Secretary of Justice, Wolfgang Stammberger, to arrest the Chief of his Intelligence Service (BND, Bundesnachrichtendienst), Reinhard Gehlen, who was sitting then in Adenauer's office. Reinhard Gehlen for his own role was an infamous yet internationally respected character as former Hitler's Military Intelligence Chief "Fremde Heere Ost" (Zolling 1971).

12 years later, when the German government was built from a social liberal coalition by Chancellor Willy Brandt, another state crisis would emerge. Willy Brandt had gained international acclaim for his politics of reconciliation between the Eastern and Western powers and was awarded in 1971 with the Peace Nobel Prize. Brandt resigned in 1974 over the discovery that his personal secretary, Günter Guillaume, was a spy of communist Eastern Germany. When arrested by the police on $24^{\text {th }}$ April 1974, Guillaume stated his military rank by revealing he was an "Offizier der Nationalen Volksarmee der DDR”. On $6^{\text {th }}$ May 1974, Willy Brandt requested from German President Gustav Heinemann his resignation from Office as Chancellor.

The investigation and prosecution of the Guillaume spy case was conducted by Federal Attorney Siegfried Buback. Buback was from 31. May 1974 until his assassination on 7. April 1977 Attorney General at the Federal Court of justice of Germany. There are claims that Herbert Wehner, Secretary General of Germany's social democratic party SPD, had been a spin doctor behind the resignation of his Chancellor Willy Brandt, who was also the SPD party leader (Leugers-Scherzberg 2002). And there are hints that the BND had information about Guillaume's spy activities already in 1954 (Guillaume 1974). It was therefore assumed that the BND had wittingly allowed him to spy and not shared the threat with the Chancellor in due course because of political calculus. Note that the BND is the intelligence service of the Chancellor.

On July $1^{\text {st }} 1975$ in a cable to the US State Department, the US Consulate reported details about the trial against the spy couple from Eastern Germany, Mr. and Mrs. Guillaume, at the Superior State Court in Düsseldorf. The trial was secret and took place in a bugproof basement room of the court, in only 100 meter distance from the Consulate (1975DUSSEL00793). Even today many of the court files are closed and state secret. It is therefore difficult to verify potential political entanglements of the Guillaume case.

Buback did not accept any guidance or impairment of his constitutional duties by political opportunism. We can assume that a smart investigator of Buback's caliber, who remained cool under enormous stress, would shed light on the darkness of terrorism, counter-terrorism, covert actions, intelligence, counter intelligence, and politics. If there was any. Buback had done so already with some success in the Guillaume spy case. In so far Michael Buback, son of the slain AG, could be right when he said (Buback 2009, Märkische 2009), "As a young boy I thought, one day the Stasi is gonna get my dad. In his entire professional life my father dealt with espionage and with treason. If somebody wanted to harm him, then because of that".

As I have already outlined, Attorney General Siegfried Buback had investigated a whole series of espionage cases - in an era when every single day two new cases were brought to prosecution 
(Bundestag 1976). This was a clear indication of infiltration in Germany and West-Berlin by spies and agents from the communist powers. Meanwhile, social democrat Chancellor Brandt approached the leaders of Germany's neighboring communist countries, which has become known as politics of reconciliation world wide. However, this reconciliation was not welcome everywhere. It had opponents in the east and in the west.

\section{The birth of left wing terrorism in the 70s}

At about the same time in western Germany, the 68 students movement became radicalized and incriminated and merged eventually in the founding of the leftist terrorist group Red Army Faction (RAF - Rote Armee Fraktion).

The student unrests in the end of the 60s merged also into a crisis, when student Benno Ohnesorg on $2^{\text {nd }}$ June 1967 was killed and student leader Rudi Dutschke on $11^{\text {th }}$ Aril 1968 was shot by Police. Dutschke, known as stellar intellectual student leader in Germany, never recovered from the gunshot to his head. Ohnesorg died from the bullet of West Berlin police officer Karl-Heinz Kurras. It is a cynical historic detail which surfaced in 2009 upon the analysis of Stasi files, that Kurras, killer of Ohnesorg, was not only a West-Berlin police officer, but also an agent of the communist Stasi secret police in East-Berlin (Müller-Enbergs 2009).

In retaliation to the increasing number of fatal casualties among the members and supporters of the extremist leftist student organizations by police officers, the "Bewegung 2. Juni" (2. June Movement, in memory of Ohnesorg killed at a demonstration against the visit of Persian Shah Reza Pahlevi in Berlin). The mission of Bewegung 2. Juni was terrorist attacks against leading figures in state and economy.

\section{Soviet resistance against prosecutions in Berlin by the Federal Attorney General}

On $27^{\text {th }}$ February 1975 members of the Bewegung 2. Juni kidnapped the christian democrat (CDU) politician Peter Lorenz in order to blackmail the German state to set free imprisoned members of the RAF. AG Buback claimed responsibility for prosecuting the case because the terrorists had coerced the Federal constitutional bodies (Dahlke 2007). Buback therefore prosecuted in Berlin and anticipated complaints by the Soviet occupation power (Lamprecht 1976).

Buback's determined pace of prosecuting in Berlin, along with overconfident public appearance and statements before the press caused serious disturbance with the Soviet representatives of the Four Powers. The Soviets felt that Buback had exceeded his authority in Berlin, to the embarrassment of the Four Powers.

An article in the 40th issue of the Spiegel (27.9.1976, "spoonful") sheds light on the repercussions that the German government experienced. At another press conference on the Lorentz case, on the 23 September 1976, Federal Secretary of Justice Jochen Vogel cut Buback of at the microphone with the words "Caution, Herr Buback!" This was six months before Buback's assassination (Spoonful 1976). 
At this press conference one reporter had asked which Federal Attorney at Germany's Head Office in Karlsruhe would have to sign the indictment. The correct answer to this seemingly harmless question should have read uncontroversial that the Federal Attorney General signs all writs from Karlsruhe. Until shortly before the press conference that would also have to apply for an indictment in Berlin as in the case Lorenz, like the last 25 years before (according Berlin Kommandantura Order BK / O (51) 63, BK / L (69) 13) (BKO 1951).

However, in September 1976, one week before the press conference, the Tripartite had interdicted with a new Berlin Kommandantura Order a general competence of the Federal Prosecutor's Office for investigations in Berlin. Such order had been diplomatically encouraged and favored by France, as is evidenced by transcripts for German foreign policy (Moller 1976). Prior to this, the United Kingdom had pushed for tighter control of the powers of the AG, as is apparent from confidential cables of the US Embassy (1976USBERL01017). Secretary of Justice Vogel feared probably another momentous utterance of the AG, who now had an officially restricted responsibility for Berlin. Because of that Vogel cut of Buback his answer to the question of the journalist with the warning: "Vorsicht, Herr Buback!"

West-Berlin Secretary of Justice Jürgen Baumann had played down the incident and said the Allies were only temporary upset about Buback meddling into affairs of West-Berlin, which had a special political status within the boundaries of the Yalta Agreement of the Four Powers, and therefore were not of the AG's business (BKO 1951).

Soviet repercussions in the Buback activities in Berlin were in fact more severe than officially admitted in the autumn of 1976. This is evident from the confidential cables between the US Embassy in Bonn and the US State Department in Washington in the years 1975 and 1976, which have been declassified and made available to the public in 2006. According to these cables, Buback had caused with his activities in Berlin considerable diplomatic complications between the Soviet Union and the United States.

In the cables, Buback's name turned up for the first time on the $16^{\text {th }}$ January 1976 in relation with his investigation of espionage cases in FRG by communist countries of Eastern Europe (1975BONN00791). It follows a chronology of the occurence of the AG in the US cables with relation to Soviet protests:

On March 17, 1975 US Ambassador Hillenbrand reported to Washington (1975BONN04346), that they would make principle considerations about the difficulties which could arise in the response to terrorist attacks, of which Berlin could be affected. This concerned possible requests for issue of firearms licenses for Berlin citizens, or the difficulty of air transport for the exchange of prisoners. At large, they were satisfied with the consultations with the Berlin and Bonn authorities, with the exception of Buback and the Bundesgrenzschutz (the Bundesgrenzschutz was a Federal Border Police Force). A positive point with the difficulties that they had with Buback was that the German authorities would work with better coordination in the future.

On March 20, 1975 the US Consulate in Berlin reported to the US embassy in Bonn (1975USBERL00553), AG Buback had been in Berlin again on 18 March 1975, where had only spoken with the West-Berlin police. The West-Berlin Senate had learnt about this visit apparently one day later in the press. 
On April 4, 1975, Soviet Ambassador Falin and US Ambassador Hillenbrand met for lunch, where Falin pointed Hillenbrand to two important issues. One was the new 4 Powers Protocol (Quadripartite Agrement, QA), and the other, according to Falin "more dangerous", the use of specific incidents such as the Lorenz kidnapping in order to create facts on the presence of the Federal Republic of Germany in Berlin - so the report by Ambassador Hillenbrand to Washington on April 5 (1975BONN05526).

On April 14, the US Embassy in Bonn reported to Washington (1975BONN05948), that they had now learned that the Soviet Union had brought forward complaints to the British and French representatives.

On 19 May 1975 Ambassador Hillenbrand reported in a 4-page letter to Washington DC and to the Embassy in Vienna about the fear of the Soviet Union, the Federal Republic was preparing a major take over of Berlin (1975BONN08055).

In May 1975, Buback moved in the center of diplomatic attention because of his involvement in the Lorentz kidnapping case in Berlin. Possibly he also took center stage with some intelligence services. The Soviet Union insisted on the special status of West-Berlin and its independence from the Federal Republic of Germany, and protested at the Three Powers that the AG of the FRG was prosecuting in West-Berlin. In a cable on 8 March 1975 to the US Embassy in Bonn, the US State Department expressed its hope that all German authorities would in future coordinate with the allies in questions relating to Berlin (1975STATE052712).

On 31 December 1975 "USBerlin" reported in a cable to Bonn (1975USBERL02657), there was increasing indication that AG Dr. Buback would assume the investigation of the Lorentz case. It would be too early for the Allies to take a position on this matter. But there had already been a precedent for that matter and it would be wise if the Federal government would permit the Allies the necessary time to consider all aspects before a final decision would be made.

They recalled the trial with RAF terrorist Horst Mahler in Berlin in 1972, where the AG had led the prosecution. They anticipated therefore new Soviet inquiries. And they pointed with reference to the $\mathrm{BK} / \mathrm{O}$ (51) 63 that the Allies had reservations about Berlin, in full understanding of the legal situation. It basically boiled down to the question whether the authority of the AG for investigation and prosecution and indictment in Berlin had its origin in Federal law or in Berlin law. The former case would constitute a breach of BK / O (51) 63. The appearances of the AG before the press had caused misunderstanding in the public, as it would turn out at a later point.

\section{Retrospect: The Connection of Berlin - German mission of utmost political importance}

The intimate relationship of the Federal Republic of Germany with Berlin was in the 70s a trigger of intense controversy. The Soviet Union would not accept a bond of Berlin to the Federal Republic. This is for example illustrated by the Soviet ambassador Falin, who met the German ambassador Allardt for discussions in Moscow on January 5, 1969. Allardt raises in his subsequent report to Bonn a warning: "At this point Falin made the remark that the position of Soviet government in the Berlin question was absolutely clear. Berlin had never been part of the Federal 
Republic of Germany and would never be part of it. All actions contrary to this would face the corresponding reactions. Incidentally, there would be complete agreement between the Soviet government and the western Allies that Berlin was not part of the Federal Republic" (Allardt 1969).

The determination with which the Soviet Union defended its position in the Berlin question, becomes also clear in a conversation between US Ambassador Cabot Lodges and Soviet ambassador Abrasimov, which is recorded in the notes of German Under-Secretary of State Duckwitz. This conversation concerned the conduction of the Federal Assembly in Berlin for the election of the German President, which the Soviet Union took as a provocation (Duckwitz 1969).

In an administrative decree by German Under State Secretary Gehlhoff from 7 February 1975, the integration of Berlin in all international agreements of the Federal Republic was to be considered a matter of constitutional relevance (Gehlhoff 1975). And we indeed observe that the official position of the United States and the Three Powers (USA, Great Britain and France) on the Berlin matter always supported the West German position that Berlin was included inclusion of Berlin in a circular by State Gehlhoff from February 7, 1975 is considered the international agreement of the Federal Republic of Germany as a task with constitutional status.

Agitation against this associating of Berlin with the Federal Republic, for example, was always guided by Soviet press organs (Barzel 1976), while the Soviet government itself officially took a more cautious approach [Allardt 1969]. The federal government pursued in this regard a clear policy, citing the Quadripartite Agreement of 3 September 1971 in which the ties between the Western sectors of Berlin and the Federal Republic of Germany would be maintained and further developed, and not commenting on adverse opinions brought forward by the foreign press (Moersch 1976). With regard to the agitations of Soviet press organs it should be added, however, that the West German press, in particular Die Welt with her prominent publisher Axel Springer had a consistent attitude to bind Berlin to the Federal Republic with the goal of the reunification (Spring 1967).

Meanwhile the Three Powers (France, Great Britain and the United States) supported officially the association between West Berlin and the Federal Republic. But they urged repeatedly for containment against West German unilateralism in matters of Berlin. An example for such containment is found in a transcript of a discussion 1970 (Scheel 1970) between German Secretary of Foreign Affairs Walter Scheel and his French colleague Maurice Schumann, in which Scheel explains that the Federal Government had the firm conviction that in all Berlin affairs, every word and every sentence, they would keep close connection with their allies. In saying so, Scheel was referring to a downright submissive expression by Chancellor Willy Brandt (Brandt 1970), which he had delivered two days before in an address on the state of the Nation in divided Germany: " $I$, ladies and gentlemen, have worked long enough in Berlin in order to know that there are things for which our shoulders are too narrow and to strive for the full sovereignty, the Federal Republic has no interest."

\section{German "Angst" for principal confrontation between USSR and USA}

In the months following the kidnapping of Lorentz, the tone of the Soviet diplomats to the representation of the Three Powers in Germany must have tightened considerably. Buback's loose 
statements in the case of the kidnapped Peter Lorentz and their implications to the role of Berlin in the Quadripartite Agreement had snubbed the Soviets and also Western Powers towards the public, as reported in an American cable sent in May 1975 (1976BONN03008).

According to another American cable, the British representativ had referred to the German Attorney General as "always difficult to control Buback" (1976USBERL01017). It came at no surprise that Buback himself had become a case. Not only for the Soviet Union and the Tripartite, but also for the Federal Republic. According to another Cable to Washington in March 1975, the Senate in Berlin (The Berlin State government is called Senate) and the contacts in Bonn had ensured through internal measures, that no longer any uncoordinated actions on the part of the Attorney General would occur (1975BONN03866).

Confidential documents of the Federal Government of 6 February 1976 show [54] that the German Secretary of Foreign Affairs (Hans-Dietrich Genscher, FDP) had demanded from the Secretary of Justice (Jochen Vogel, SPD) that Buback would not act any further in matters of Lorenz and with regard to Berlin without prior consultation with the German Foreign Affairs Department. Obviously Buback had brought the German government into a highly explosive situation, which is signified by a statement from Councilor Mr. Lücking (Lücking 1975): "We are heading for a new confrontation with the three powers. They fear a fundamental confrontation with the Soviet Union ... ".

The day before, Secretary Meyer-Landrut of the Department of Justice reported at a meeting of the Bonn Group of Four (committee of representatives of the three Western powers and the Federal government) about indiscretions of particular Berlin sources to the press. The spokesperson of the Three Powers responded that experts obviously tried to influence the decision of the Three Powers by a press campaign. The German side should clearly understand if that press campaign would be to continue, then the matter would gain a political dimension in which the decision of the Tripartite no longer were be made solely by criteria of legality, but also of political expediency."

Obviously, the behavior of the Federal Public Prosecutor was still reason for Allied observation and intervention. The US embassy reported to Washington from the aforementioned press conference to the question of who would sign the indictment of the alleged Lorentz kidnappers, citing Federal Secretary of Justice Vogel who issued the warning "Caution, Herr Buback." (1976USBERL02003)

About six months later, on 1 February 1977, USBonn reported to Washington that Secretary of Justice Dr. Hans-Jochen Vogel wished to visit the United States and meet with authorities in matters of fighting terrorism. However, he would need an authorized invitation. The best occasion for this would be an invitation with respect to finalizing a mutual extradition agreement (1977BONN01925).

The activities of the Attorney General in Berlin threatened the very fabric of Yalta and thus affected the fundamental interests of the Four Powers. Escalation was imminent. On August 6, 1976, the reigning Soviet Councilor Tyutyunov protested to the US Foreign Policy Advisor (POLAD) at the US Mission in Berlin, "the Soviet Union expected that the authorities of the three Western powers fulfill their obligations under the Quadripartite Agreement and take appropriate measures to prevent the illegal intervention of the Attorney General at the envisaged trial in Berlin". (1976USBERL01631) 


\section{Always difficult to control Buback: "Der General muss weg"}

The reactions of the Allies to the unilateral action of the AG and his indifference or even ignorance of Allied reservations and sensitivities were likely met with disapproval by the German government. Is it possible that Bonn had developed second thoughts over the appointment of Dr. Siegfried Buback as Attorney General in 1974?

If so, then terrorists Andreas Baader and Gudrun Ensslin had not been the only ones, and perhaps not the first ones who had wished for an end of Buback's relentless and aggressive investigations with the postulation, the "Der General muss weg" (The General must go). Supposedly, Baader and Ensslin had sent a secret message via their attorney to other terrorists outside the prison. In this message they ordered with the above quote the execution of Generalbundesanwalt Buback. When terrorist and terrorist attorney Siegfried Haag was by coincidence arrested on 30 November 1976, documents found on him (Haag papers), contained the above execution order which was labelled "Operation Margarine". One German margarine brand is named "SB", but police did not interpret

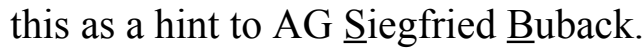

Since Baader and Ensslin are dead, they cannot be interviewed anymore about this allegation that they gave command to kill Buback. Hence, the question for the origin of the Haag papers as well as the secret message from prison to outside is lacking original answer as much as the question for the actual drivers and shooters on the motor bike.

During the Stammheim trial Andreas Baader issued on 28 October 1975 a statement regarding to torture and solitary confinement. This statement can be understood as a threat against the presiding judge Theodor Prinzing (Prinzing 1975): “... OK, but we make it short. Rejection (of the judge: the author). It is anyway a farce with this Court Senate here. One cannot get rid of him here in any way. But I just want to state briefly about this. We are confident, Prinzing, that you are working here on your very own sentence". (Baader 1975). Did RAF-terrorist Baader announce here the assassination of judge Prinzing?

Federal Attorney Griesbaum claims (Griesbaum 2011), and so it reads in the court records (OLG 2012), that the planning for the killing of Buback was committed jointly from within the RAF group. Even if this assessment was correct, it would not be sure if the RAF group had selected Buback as target. Whether Haag and Mohnhaupt received the order "The General must go" from Baader and Ensslin when they were in Stammheim prison, or from someone else - we do not know.

The question about who is the actual perpetrator, is being discussed ambivalent in an article in the "Spiegel" (Sattar 2009). It had been Baader who had initiated the smuggling of the secret message to the outside as an ordered assassination. RAF-terrorist Peter Jürgen Boock told as a witness in court in the case against Verena Becker, the secret message with the murderous contract "the General must go" had made its way to the terrorist camp in Aden as a smuggled letter from the Stammheim correction facility (Geiger 2011).

Interviews with terrorists of the RAF and the 2 June Movement indicate that Siegfried Haag, who shared his room in the training camp in Yemen with Verena Becker, had requested in a brainstorming with RAF terrorists in the camp a list with suggestions for assassins. When Siegfried Buback's name showed up on the list, Haag had expressed satisfaction. If this was true, it would be 
quite conceivable that Haag had Buback's name as victim already in mind, but was waiting for the name to come up from the group.

Haag had emerged from the group of German terrorists in the camp as their leader. Apparently, PFLP (People's Front for the Liberation of Palestine) leader Wadie Haddad had insisted that RAF was presented by a leader because he did not want to negotiate with a whole group. Having a leader was actually a violation of the school of thought of the RAF and the June 2 Movement, who had no official leader and based their decision on consent of the members. It is conceivable that Siegfried Haag had been injected as a RAF group leader by the Palestinians, which were under the influence of the Soviet Union. It remains a hitherto unproven speculation that foreign intelligence services by means of the PFLP had access to and influence on those RAF and June 2 Movement members, who were not yet imprisoned (Illegale), and that Siegfried Haag and possibly Verena Becker received orders and assured that particular, and only particular individual leaders became targets in the Federal Republic (Buback, Ponto, Schleyer) and were executed. Solitary confinement of Baader, Ensslin and Raspe warranted that no alternative or contrary order would reach the group of illegals outside. Eventually, the execution of three leaders was assigned to the Baader-Meinhof gang.

Dr. h.c. Harald Preusker (Chairman of the German Association of Directors of Correctional Facilities) said that the smuggling of secret messages is a downright prison typical means of communication with the outside world by inmates and not necessary an indication of a particularly criminal mindset (Preusker 1992).

The question, how the so-called Ensslin-Kassiber made its way from the prison into Ulrike Meinhof's hand is to date not resolved. Gudrun Ensslin's defense attorney was accused of having smuggled Ensslin's secret message from the prison in June 1972. Otto Schily (founding member of the German green party, member of the social democrat party and Federal Secretary of Interior from 1998-2005) was thus facing the exclusion from the judicial process as the trial lawyer (Schily 1972). Schily however insisted that he had neither smuggled nor forwarded this secret message. Charges against him were eventually dropped, but only because of constitutional reasons.

Concerning the Haag papers, the cooperating witness Gerhard Müller claimed before the court that RAF members had been in the belief that the defense lawyers had smuggled the secret message with the order for the killing of Buback (Mengen 1976).

Furthermore, of course, the authenticity of secret messages can be put in question par excellence. A (false) Kassiber could certainly be smuggled from an external party into a terrorist organization. This would be conceivable, for example, for an externally controlled trial lawyer who takes a real secret message, distorted it and forwards. Or the defense lawyer or one of his staff could bring a fabricated secret message in circulation.

In the Stern issue from 27 April 2007 (Knobbe 2007), journalist Martin Knobbe reports about memory logs of conversations between Federal Attorney Joachim Lampe and the two presumed RAF terrorists Volker Speitel and Hans-Joachim Dellwo. These conversations supposedly permitted a glimpse into the internal mechanisms of the RAF. Speitel explained how the communication between the inmates in the prison and the illegals outside proceeded outside. According to Lampe, Speitel had been so scared of the suicides in Stammheim, that he had avouched to everything. Speitel was apparently in the believe that the reported suicides of RAF terrorists Baader, Ensslin and Raspe in the Stammheim prison were in fact extrajudicial executions by the government. I believe this report reads a bit too theatrical, as if Federal Attorney Lampe was protesting too much. 
Speitel would himself contradict here, because the Spiegel writes (Speitel 1980, Siedler 2008) that RAF terrorist Speitel would not lend into the story of extrajudicial killing. It is noteworthy that Speitel and Dellwo, who were cooperating witnesses, received only minor prison sentences for their confessions. Like RAF terrorists Gerhard Müller (Kerscher 2010) and Siegfried Haag, and like agent provocateur Peter Urbach, they disappeared from the scene.

Whereas terrorist Baader posed an open threat against Senate chairman Prinzing, who is still alive today, AG Buback actually was murdered, although no open threat was expressed against Buback by the RAF gang. There is tragic irony in the fact that Buback's superior, Secretary of Justice Vogel, issued at Buback the warning "Caution, Herr Buback."

Rather, there is only the secret message "the General must go", whose source raises even more questions like the ways of the Ensslin-Kassiber. Notably, both Buback and Prinzing were counted among the high profile people at risk.

\section{Actions with unclear goals by actors with unclear identity}

The Haag-papers are subject to a certain, even double question mark. On the one hand we have as indication of the threat only the two letters SB in a not very clear context. Even if the connotation S.B. = Siegfried Buback was true, we may beg the question who actually assigned the target.

Lawyer and convicted RAF terrorist Siegfried Haag was suspected of playing a double game because he had worked for at least one secret service, the Eastern German Stasi.

Verena Becker and Günter Sonnenberg were arrested in Singen 1977 after a shootout with police. While both were in the possession of the weapon which was used for Buback's assassination, it was only Sonnenberg who was accused and convicted for the murder. The US Embassy in Bonn noticed this distinction and informed the State Department in a cable about this singular indictment (1977STUTTG00759).

It is striking that Becker, pretty much like Haag, received relatively short imprisonment, as Michael Buback remarked recently in a telephone interview with Alexander Benesch (Benesch 2012).

Former Secretary of Justice Gerhard Baum remarked in an interview (Köppchen 2007) that some RAF members had accepted sentencing although they were innocent, whereas some other actual culprits had not been sentenced. Baum hoped that the apparent conspiracy of silence would break soon. But this has not yet happened.

Ambiguous charactors like Siegfried Haag and Verena Becker, of whom the public still does not know whether they are only terrorists, agents of domestic or foreign intelligence services, or both, ostensibly always led to a concealment of the actual conditions and relations in terrorism. The same applies to the agent provocateur Peter Urbach, whose duplicity is court proven (De Graaf 2011).

Is it maybe a flaw when we assume for terrorists per se one identity, one single role? Can terrorists play roles which are contradicting the laws of logic, at least from the perspective of an outside observer? Do terror organizations and secret services and similar structures possess one clear identity? Doesn't it seem sometimes that we are dealing with a dual nature?

In the complex mixture of political opportunism, in the counterplay and interplay of competing ideological, political and economic interests Buback was maybe not only an eyesore to the Soviet Union and the German Democratic Republic and its Ministry of State Security (MfS, "Stasi"). 
During the social-liberal coalition government, the Federal Republic, the government, the military and even the political parties were infiltrated by Communist agents. It would be an naive assumption that the leading figures in government and administration would not have guessed so at least. West German intelligence must have been aware of the infiltration. Ignoring the fact of espionage or its denial can be considered a pragmatic approach in daily governance. With view of more important political interests Willy Brandt may have ignored the entire espionage questions of his time. The opposition however cannibalized the consequences of negligent behavior from their point of view of domestic policy. There is evidence that Brandt's resignation in 1974 was fueled by some of his colleagues in the SPD. Beneficiaries of this resignation was not only Brandt's successor Helmut Schmidt, but also hardliners and "realists" at the left wing of his party. It can be assumed that the opponents of Brandt's policy of detente resided probably on both sides of the Iron Curtain and, following Brandt's resignation, heralded the tentative end of the détente, which had been awaited by many people and which was officially supported by the four powers. The unmasking of communist spies whose most prominent representative as Günther Guillaume is in our memories, could thus far also have been a pretext to stop the further rapprochement between Germany and the East.

CDU and CSU had a clear and condemnatory attitude towards left-wing extremism, which they equated with radicalism and even with terrorism, as evidenced by a critical documentation of the Konrad Adenauer Foundation (KAS 1977). They also condemned the numerous intellectuals in politics, culture and science, who expressed understanding for the social and political change, which was demanded by the ' 68 generation.

The assassination of the Attorney General represents a culmination and at large a turning point in the history of terrorism in Germany. Historians commissioned by the German Department of Foreign Affairs assess 1976 as "beyond the apex of the era of detente. The threatened strategic balance in Europe, the growing Soviet influence in Africa and the implementation of the Helsinki Final Act. Were the worries of the German government in 1976" (Pautsch 2007).

While the detente towards the East was officially at the heart of the Three Powers, the ideological east-west border was not only a reality within the quadripartite. Some of the details in the secret cables of the US and the records of the German foreign policy can certainly be interpreted to the effect that the East-West border was mentally even more present in the government than politically. Probably this border went even throughout the midst of the Social Democratic Party SPD.

It is equally important to note that despite all the ideological differences, the political opponents respected the positions of their internal political opposition. Such as Chancellor Helmut Schmidt in his negotiations with Soviet Ambassador Falin over an economic agreements with the Soviet Union which would reach far over several decades in the future. The left wing opposition in Germany (at that time the CDU), said Schmidt, must be involved (Ruete 1970). Or the constant exhortations of the three Western powers to the federal government to consider the position of the Soviet Union with a view to the Quadripartite Agreement and to instruct the attorney general when it comes to Berlin accordingly.

On the 26 October 1976, half a year after Buback's assassination and one week after the deadly night of Stammheim when RAF terrorists Bader, Ensslin and Raspe died and Irngard Möller surviced with severe injuries in prison, Chancellor Schmidt shared with Soviet ambassador Falin (Schmidt 1977) his view on international terrorism in general and terrorism in Germany in 
particular. Schmidt mentioned there were hints that the umber of terrorists was only about two dozen and that they had submerged into foreign countries. Falin's view is not reported. Today is obvious that many suspected RAF terrorists had found refuge in the DDR. For the top politicians like Schmidt this might have been a guess back in 1976. But for particular individuals in the German and other western secret and intelligence services this knowledge might have been a certainty.

Below the top level government there is the top level administrative service, which is not subject to the permanent change by frequent political elections. This level conducts its own independent life, so-to-speak. I want to refer to one particular example which was expressively mentioned in the very same conjecture which I want to draw here. The German Bundesgrenzschutz was mentioned in one US cable as a problem to the Soviets with respect to Berlin (1975BONN04346). Dr. Dieter Rogalla, former government officer with the customs service, then socialist party member of European Parliament in brussels and later high ranking member of the EU commission, called the Bundesgrenzschutz part of the "deep state" (Rogalla 1987) in as it conducted its own way of fighting terrorism without explicit approval of the Federal government. If this was coincidence or actual planning, we do not know. It is also conceivable that the lower management does deliberately not inform the Minister or Chancellor, so that in case of failure the top leader can not be held in liability (Komossa 2014). This way of protecting a leader is in contrast to the case where it is assumed that particular actions of foul play could not have been done without the backing of senior management. And finally, there is the possibility that military, security forces and intelligence agencies are completely under alien control, as has been the case for example in Italy according to prime minister Giulio Andreotti (Igel 2006).

This account of separation of governance from elected government and constitutional accountability sheds a doubt on the legitimation of some government business. Michael "Bommi" Baumann, terrorist of the Bewegung 2. Juni, was wondering, for example, how the freeing of the hostages in the kidnapped Landshut airplane in Mogadishu, Somalia in 1977, became so straightforward and successful. The reaffirmation of GSG 9 boss Ulrich Wegener, that the release of the hostages would work for sure in Mogadishu, raises the question of why and how Mr. Wegener could be so sure back then in 1977. Baumann's suspicions that the freeing of Mogadishu had involved a cooperation of Eastern and Western intelligence services, reads credible.

The US cables had the kiling of Buback and its aftermath until October 1977 on their radar (1977USBERL03045), but after that the Buback case was finished and the complex of the quadripartite status of Berlin was apparently pacified. About the RAF there was an ongoing debate, but no further actions from the terrorists. There was also no further politically sensitive unmasking of spies more.

Terrorism expert Dahlke finishes his essay (Dahlke 2007) by noting that the kidnapping of Lorentz had shown how intertwined the ways to today's accountability in the fight against terrorism had been (Tams 2007). Complementary to this the unresolved assassination of Buback shows how intertwined the way to the former responsibility of terrorism may have been. The metaphor of terrorism as a box with a false bottom, as terrorism expert Kraushaar has put it (Kraushaar 2006), is thus a quite appropriate term. 


\section{Why Buback? Why not Prinzing?}

Attorney General Dr. Buback and the presiding judge of the 6th Criminal Criminal court Dr. Theodor Prinzing were both considered potential targets by the police. I mentioned in the previous section that Andreas Baader had threatened the judge at his trial (October 28, 1975: "We are confident, Prinzing, that you are working here on your very own sentence”. (Baader 1975)). On January 13, 1977 information surfaced that Prinzing had sought counsel with members of the 3rd Criminal Senate at the Federal High Court prior to critical decision making in his own Senate. This $3^{\text {rd }}$ Senate was the Appeal Court. Correctly, the public defender of Baader considered this as an indication of the judge's partiality. Whereas countless appeals by the choice defenders for partiality of the judge had not been considered, this one filed by the public defender was considered and the request for bias granted. Judge Prinzing had to resign from the Senate (Mauz 1977).

Kühnert provides in his article in "Die Zeit" of February 4, 1977 a brief chronology of the resignation of Prinzing. To some extent, the portraits of Buback and Prinzing look similar ("ambition, sense of order, an almost love-hate relationship with the public, urge for probation had been were Prinzings motifs that pushed for the chairmanship for the process.") (Kühnert 1977). Overall, however, Prinzing is sketched in the article rather as a weak character, while Buback after all can be described as cool, secure and self-confident.

No later than with Baader's threat at the trial, Prinzing had to be considered as a potential victim of an attack. However, the last of the countless requests for dismissal of Prinzing because of partiality was successful, and Prinzing was removed from court. After this there was no serious reason for an attack on Prinzing, as Prinzing points out in an interview with the Tagesspiegel (Prinzing 2007).

Buback, in contrast, presented a strong character which was robust against any form of compromise. For example, he had turned against a policy of making deals with cooperating witnesses, specifically from fundamental constitutional considerations and by conviction, as he had made it clear in a much-publicized interview (Lamprecht 1976). In the same interview Buback commented on the good cooperation with the chief of the Bundeskriminalamt Mr. Herold (German Federal Bureau of Investigation) : "State protection is run by people who are committed to it. And people who are committed to this, like Herold and me, will always find a way."

This statement of Buback was interpreted by liberals and leftists as a conspiracy of executive and judiciary, and thus would be a fundamental violation of the constitutional premise of separation of powers, of checks and balances.

The authors of the letter of confession for Buback's assassination wrote in a cynical note: "for actor's of the system itself, history will always find a way", thus resembling Buback's own words.

Herold on the other hand, had distanced himself from Buback's description of the cooperation of the BKA and Attorney General, and Buback's interview was a matter of controversial debate in the German parliament (Deutscher Bundestag) (Prantl 2010). Buback attracted also international criticism because he prosecuted some of the defense lawyers which had been appointed by the accused terrorists; some of these lawyers were excluded from the court proceedings (Spiegel 1975). 


\section{Experts fanning the flames in the media}

The newspaper "Die Welt" and its publisher Axel Springer appeared repeatedly in provocative context in the Berlin conflict. Axel Springer had a personal, maybe romantic relationship to Berlin as the capital of Germany. There could be the origin of some of the confrontation in news releases about the separation of Berlin into East and West Berlin, the kidnapping of Lorentz and the official business of Buback in Berlin (Springer Wiki). There is a cable to Washington reporting that Axel Springer had requested a gun license in Berlin, so that he could defend himself if there was an attack on him (1977USBERL03045).

"The press" was apparently attempting to gain influence on public, political matters. This becomes clear in an address by German President Walter Scheel 1977, in which he warns of the concentration of press organs and the abuse of the freedom of the press (1977STUTTG01728). More than 15 years before US President John F. Kennedy had warned in a similar speech of the abuse of the freedom of the press and called for journalists to act responsible (Kennedy 1961). The US cables and the reports from the German Foreign Affairs archives give an account how the Four Powers and the German Government accused the press of unwished-for influence on the Berlin policy (1976USBERL02003). There is at least one case reported in the US cables that a correction notice about the competence of the Federal Attorney General in Berlin was demanded and published from a newspaper in Berlin.

As is apparent from the Cables of the US Embassy and the file on foreign policy, the press was an undesirable influence on the part of the Allies as well as the federal government accused the Berlin policy (1976USBERL02003. In at least one case has been demanded by Berlin newspapers that they published concerning the competence of the federal corrections in Berlin.

\section{Summary and Perspective}

Respectable politicians like former Federal Secretary of justice, Gerhart Baum or a chemistry professor like Michael Buback, who stands as a scientist in the reputation for being committed to objectivity had the opinion that the trials around the terrorist cases were not entirely above board.

Some of the trials of terrorist attacks and terrorist support crimes were fraught with concerns over shortcomings in the truth, last but not least the trial for the Buback assassination. Another example is the case against Monika Haas, who was accused of being involved in the kidnapping of the Lufthansa aircraft to Mogadishu. Decisive for her conviction was a testimony from an anonymous intelligence official (Haas 2000). Rightly, therefore, the question was asked, why terrorist cases are not sufficiently solved by the police and judiciary (Bolesch 1991).

Terrorist Vereny Becker had noted in her diary, which was seized by police, that the assassination of Siegfried Buback was a "dirty story" (Buback 2012a). Becker has been convicted in the killing of four men. If according to her human standards Buback's assassination was a "dirty story", then this case must be more than just the murder of an AG by a terrorist, so the son of the slain AG in his coplaintiff plea at the trial in 2012 (Buback 2012b). Therefore, Michael Buback had asked Verena Becker what she had actually meant by "dirty story" (Buback 2012b), after she had read a statement 
before the judge, in which she protested her innocence (Hünninger 2012).

On June 6, 2015, Wolfgang Schäuble, prominent christian democrat politician and former Secretary of Finance, Secretary of Interior and Secretary of Special Affairs to the Chancellor Helmut Kohl, rejected rumors that the Federal German authorities had had knowledge about cooperation of RAF terrorists with communist secret services for their save harboring in the DDR (Dittrich 2015). Compare this with Chancellor Schmidt talking with Falin in 1978 and his assumption that terrorists were only a handful and probably had submerged abroad.

Whether assertions that nobody in the West-Germany government knew about such cooperation, are credible or not, remains open. Given, however, that the government provided save harbors to accused terrorists who served as cooperating witnesses, there is no doubt that government or administration had instruments at hand to provide terrorists and witnesses turning state's evidence with a future in anonymity (Spiegel article: "CID and Attorney General have embarked on shady deals with terrorists.") (Müller 1979).

An old quote says, "Nowhere is as much a lie as to justice." Therefore we cannot count on justice at the court. What we get is a verdict, which happens to be the opinion of the court. We can make our own judgement based on court records, speeches, press releases and individual opinions of informed observers, witnesses, eyewitnesses and actors and from the meanwhile accessible confidential official reports, notwithstanding that the nature of the matter makes its sources prone to disinformation, too.

On April 15, 1977, the US Embassy reported to Washington that Federal Attorney Dr. Heinrich Wunder had made a conjecture between the killers of Buback and the RAF inmates in Stammheim by posing the question, whether the killers of Buback had been following old orders (1977STUTTG00651). Such conjecture exists because of the aforementioned Haag papers. To what extent the Haag-papers may be considered as authentic to the RAF, has already been discussed in this manuscript.

There is little doubt that Attorney General Dr. Buback had become a burden for a number of stakeholders, and for some of them he had become even a threat. His investigations in the RAF trials would have potentially brought to surface contradictions and questions, which could have interfered with secret services, intelligence agencies and leading, unknown figures behind them. With the dispute of the Four Powers over Berlin, the RAF trial in Stammheim and possible discovery of linkage between terrorism and politics, and policy, probabilities for an assassination of Buback simply had densified in the year 1976.

Who was behind the assassination of Siegfried Buback, is at best a matter of presentiment. The high professionalism with which the assassination was carried out suggests that highly skilled and trained professionals were at work. The author of this paper is not absolutely convinced that the RAF terrorists who were in the center of the investigation and who had received the instructions and training in Yemen, had the necessary stature for carrying out the aformentioned attack on buback and his companions.

Supposedly, RAF terrorists Baader, Ensslin and Raspe gave the order for the execution AG Siegfried Buback when they were inmates in the Stammheim high security prison in solitary confinement. Actually, Baader threatened presiding judge Dr. Theodor Prinzing in his trial. While Baader explicitly implicated judge Prinzing as target, Buback in his capacity as state operative was 
a target, the assassination of which would have caused higher operational impact. Buback had become a burden, not just a nuissance for the foreign relations among the four powers and the relations between the FRG and the four powers at the demarcation line between East and West. If Buback had continued working,

The personal security provisioned by the State was in the end no protection for Buback.

\section{References}

Abrahamsen, R. 2005. "Blair's Africa: The Politics of Securitization and Fear.” Alternatives: Global, Local, Political 30 (1): 55-80.

Pedersen, B. 2015. Ermittlungen zu Buback Attentat eingestellt. RAF - „,Die Bundesanwaltschaft hat ihre Ermittlungen gegen mehrere ehemalige RAF-Terroristen wegen des Mordes an Siegfried Buback eingestellt.“ dpa, in: Zeit Online - Zeitgeschehen vom 19. Mai 2015.

http://pdf.zeit.de/gesellschaft/zeitgeschehen/2015-05/raf-siegfried-buback-rote-armee-fraktion.pdf

Greven, L. 2012. Becker-Urteil-Die vergebliche Mission des Michael Buback. Die Zeit, 6. Juli 2012.

Schmid, H. 2014. ARD national broadcasting service terrorism expert Holger Schmid discovered the radio interview of reporter Ulf Stuberger with the Deutschlandfunk from the early morning of April 7, 1977 in the archive of the SWR broadcasting service and put it online on Dec. 5, 2014 at http://www.swr.de/blog/terrorismus/2014/12/05/buback-mord-auf-dem-motorrad-soll-eine-jungefrau-gesessen-haben/

Leyendecker, H. 2010. "Die RAF und Verena Becker, Nur die innere Stimme spricht." In December 2008 the Attorney Generals Office had a four hour discussion with the family members of the murdered RAF-victims and declared, Becker could be ruled out as killer. Süddeutsche Zeitung, May $17,2010$.

http://www.sueddeutsche.de/politik/die-raf-und-verena-becker-nur-die-innere-stimme-spricht1.170405

taz. 2008. "Neue RAF-Verdächtige im Fall Buback - Ermittlungen gegen Verena Becker",die tageszeitung, June 6, 2008. http://www.taz.de/!5180997/

Buback, M. 2009. “Der Zweite Tod meines Vaters”. Taschenbuch, Knaur TB, 01.10.2009, 448 pp.

OLG Stuttgart, 2012. Az.6-2 StE 2/10. Urteil vom 6. Juli 2012 in der Strafsache gegen Verena Becker wegen Beihilfe zum Mord in drei tateinheitlichen Fällen.

Buback, M. 2012. "Schlussvortrag von Michael Buback in der Hauptverhandlung gegen die Heilpraktikerin Verena Christiane Becker". Plea of co-plaintiff at the trial against Verena Becker. "The first was, as just shown, apparently directly involved in carrying out the crime, but was not charged. For the other two, it is the reverse: It has now turned out, that they were directly involved in the attack, but they were tried and convicted." http://www.3sat.de/kulturzeit/pdf/Buback_Plaedoyer_140612.pdf

Croissant, C., Groenewold, K., Preuss, U.K., Schily, O., Stroebele, C. 1976. „Politische Prozesse 
ohne Verteidigung?"“(Political trials without defense?) Editor: Wolfgang Dreßen. Klaus Wagenbach, Berlin 1976, Politik 62.

Diewald-Kerkmann, G. 2005. „Im Vordergrund steht immer die Tat ..."Rechtsgeschichte Zeitschrift des Max-Planck-Instituts für europäische Rechtsgeschichte, 2005, 7, 138-152. "In the center is always the deed ..." Whereas the accusation at trial was fabricated as the membership in an organization, because there was no evidence for any particular crime, as defense attorney Kurt Groenewold brought forward in the trial against himself. See also Frankfurter Allgemeine Zeitung, January 31, 1978.

Friedrichsen, G. 2012. Verena Becker im RAF-Prozess: "Ich war nicht dabei". ("I wasn't there") Der Spiegel, May 14, 2012.

Andrawes Sayeh, S.S. 1995. „Ich war noch ein Kind“ (“I was still a child”). Landshut aircraft hijacker Souhaila Sami Andrawes Sayeh gives interview for Der Spiegel. Issue 3/1995, pp 79: SPIEGEL: Did you get any introduction prior to the hijacking?

Sayeh: Heaven no! Two months before there was some kind of training for all members of the political organization. Some gymnastics, judo, a little bit self-defense and training on weapon: open, load, shoot. We tried to learn this with closed eyes. Few days before the flight to Mallorca there was a short rehearsal. Everybody threw a grenade. This was more like a psychological preparation, not a real training.

Deutscher Werberat, 1977. German Council for Ethics in Commercial Advertising. https://www.werberat.de/die-70er Geworben wurde mit der Aussage "Die Sportskanone für Scharfschützen".

Klöckner, M. 2012. „Keine offene Ermittlung“. Buback-Bruder rechnet mit Deutschland ab. Interview with Co-Plaintiff attorney Matthias Rätzlaff. Focus Online, July 4, 2012.

Schmidt, H. 1977. Chancellor Helmut Schmidt Bundeskanzler Helmut Schmidt in his speech at the memorial ceremony for murdered Buback and companions on April 13, 1977: "Er war ein harter Kämpfer für das Recht, für die demokratische Grundordnung, für die Sicherheit der Bundesrepublik Deutschland. " (He was a tough fighter for justice, for the democratic constitution and for the safety of the German Federal Republic). Schmidt, Helmut; Buback, Siegfried; Göbel, Wolfgang; Wurster, Georg. Bulletin des Presse- und Informationsamtes der Bundesregierung, No. 35 (1977), p. 321-324.

Ahlers, C. 1962. Bundeswehr - Strategie - Bedingt abwehrbereit. (Bundeswehr - StrategyLimited preparedness). Der Spiegel Nr. 41/1962 , pp. 37-53. October 10, 1962.

Spiegel 1965. Ahlers Verhaftung - Bitte buchstabieren Sie. (The arrest of Ahlers. Please spell the name). Der Spiegel Nr. 25/1965, June 6. 1965, 23-34.

Spiegel 2012a. Spiegel Affäre: Schmidt in Bubacks Visier. Der Spiegel 39/2012, page 76. The article contains excerpts from the transcript of the inquisition of Spiegel publisher Rudolf Augstein in custody with Federal Attorney Buback. Among all Spiegel journalists, Augstein remains longest in custody, even over Christmas. Federal Attorney Buback pulls him out for inquisitions over and over again. And he always arrives at one person: Helmut Schmidt. 
Buback: "Is it possible, that you marked the file collection with following side note: 'Helmut Schmidt's view'?"

Augstein: "This is possible, but I have no memory. I do not memorize a context, where such relation would be reasonable."

Buback points to the citation, and Augstein responds: "I have no memory."

Buback: "Is this name Helmut Schmidt the very Hamburg Senator of Interior?"

In January 1963 the Attorney Generals Office launched the investigation against Hamburg Senator of interior Helmut Schmidt for complicity in treason. Schmidt steps not down from office because he and his friends from the SPD and leading CDU members agreed to "keep the case low profile" (see Interview page 74).

Spiegel 2012b. „,Umtaufen in Strauß-Affäre“ (Change names from Spiegel affair to Strauss affair). Ex-Chancellor Helmut Schmidt, 93, about the investigation launched against him in 1963 and his personal contacts with Spiegel journalist Conrad Ahlers. Der Spiegel 39/2012, pp 74-75; Spiegel: "Did you have the impression that the Attorney General's Office really thought you were involved in treason?"

Schmidt: "This I don't know, but they represented the case with zest. Since then my relationship with the Attorney General's Office was impaired."

Zolling 1971. "Was Gehlen verschwieg" (What Gehlen did not tell. White patches in the memory of the former BND intelligence chief and founder - A conversation with secret service expert Hermann Zolling). DIE ZEIT (Nr. 42), Oktober 15, 1971. Chancellor Konrad Adenauer commanded his Secretary of Justice Mr. Stammberger: ,You must arrest Mr. Gehlen. ' Because Gehlen was believed to have leaked the preparations against the Spiegel to one of his subordinates, Colonel Wicht.

Leugers-Scherzberg, A.H. 2002. Herbert Wehner und der Rücktritt Willy Brandts am 7. Mai 1974 (Herbert Wehner and the resignation of Willy Brandt on May 7, 1974). Vierteljahrshefte für Zeitgeschichte Jg. 50 (2002) ; Nr. 2, pp. 303-322.

Guillaume 1974. Der Fall Guillaume. Der Spiegel 41/1974.

1975DUSSEL00793. The National Archives (NARA) (Access to Archival Databases) AAD, US State Department, Cable Document Number 1975DUSSEL00793. „Subject: Guillaume spy trial opened in Duesseldorf" vom 1. Juli 1975. http://aad.archives.gov/aad

Buback 2009. Prof. Dr. Michael Buback, Hannoversche Allgemeine, May 25, 2009.

Märkische 2009. Märkische Onlinezeitung September 25, 2009, http://www.moz.de/artikelansicht $/ \mathrm{dg} / 0 / 1 / 75965$.

Bundestag 1976. Deutscher Bundestag, Stenographischer Bericht, 226. Sitzung, Bonn. Parl. Staatssekretär Dr. de With auf die Frage von MdB Spranger (CDU) nach der Zahl der eingeleiteten Ermittlungsverfahren in der BRD bzgl. Spionagefällen aus der DDR und Ostblockstaaten seit Anfang 1975. Mittwoch, den 10. März 1976.

Müller-Enbergs, H., Cornelia Jabs, C. 2009. Der 2. Juni 1967 und die Staatssicherheit, Deutschland 
Archiv: Zeitschrift für das vereinigte Deutschland, 42 (2009) 3, S. 395-400.

Dahlke, M. 2007. „Nur eingeschränkte Krisenbereitschaft“ Die staatliche Reaktion auf die Entführung des CDU-Politikers Peter Lorenz 1975, Vierteljahreshefte für Zeitgeschichte 2007, 55(4) 641-681.

Lamprecht W., Sternsdorf, H.-W. 1976. „Der Rechtsstaat auf dem Hackklotz“. Interview with AG Buback: „Von Bedenken der Alliierten ist mir nichts bekannt. Natürlich müssten wir sie vorher unterrichten - schon damit sie uns abdecken, wenn der Osten protestiert."

("I have no knowledge about reservations of the allies. Of course we need to notify them beforehand - so as to prepare for potential protests by the East")

Der Spiegel nr. 6/1976, pp 30-38.

Spoonful 1976. „Ein Löffelchen“, September 27, 1976, pp 116-118.Der Spiegel 40/1976,

BKO 1951. BK/O (51) 63: Letter of the Allied Command of Berlin dated November 13, 1951 concerning the competencies of the occupation authorities to the Acting Mayor and the President of Berlin Parliament "claryfing particular relationships which arise from the constitutional status of Berlin."

See also „Studien und Gutachten aus dem Institut für Staatslehre, Staats- und Verwaltungsrecht der Freien Universität Berlin, Heft 5, Das richterliche Prüfungsrecht in Berlin, by Dr. Peter Hauck, Verlag Duncker \& Humblot / Berlin 1969.

Moller, H., Hildebrand, K., Schollgen. G. 1976. Akten zur Auswärtigen Politik der Bundesrepublik Deutschland. Records by Feit, July 8, 1976.

1976USBERL01017. NARA AAD, US State Department, Cable Document Number 1976USBERL01017 from May 13, 1976. „As Embassy will be aware from Reftels which repeated relevant intra-Berlin messages, we have for some time adopted reserved attitude toward project pushed by British to revise BK/L(69)13 to provide formally for earlier and tighter control over activities of federal prosecutor in Berlin. ... It thus seemed appropriate to await an opportunity when we could amend $B K / L$ without creating implication that we were critical of German behavior, for example at such time as one of various draft bills now in Bundestag that would strengthen role of Federal Prosecutor in combating terrorist activities became law."

1975BONN00791. NARA AAD, US State Department, Cable Document Number 1975BONN00791; Arrest of nine individuals suspected of industry espionage for an eastern intelligence service, reportedly the KGB, to the disadvantage of IBM. https://aad.archives.gov/aad/createpdf?rid $=116323 \& d t=2476 \& d l=1345$

See also1975STATE011158, https://aad.archives.gov/aad/createpdf? $\underline{\mathrm{rid}=116027 \& \mathrm{dt}=2476 \& \mathrm{dl}=1345}$

1975BONN04346. NARA AAD, US State Department, Cable Document Number 1975BONN04346, https://aad.archives.gov/aad/createpdf?rid=206551\&dt=2476\&dl=1345

1975USBERL00553. NARA AAD, US State Department, Cable Document Number 1975USBERL00553, https://aad.archives.gov/aad/createpdf?rid $=209052 \& \mathrm{dt}=2476 \& \mathrm{dl}=1345$ 
1975BONN05526. NARA AAD, US State Department, Cable Document Number 1975BONN05526, https://aad.archives.gov/aad/createpdf?rid $=14046 \& d t=2476 \& d l=1345$

1975BONN05948. NARA AAD, US State Department, Cable Document Number 1975BONN05948, https://aad.archives.gov/aad/createpdf?rid=13903\&dt=2476\&dl=1345

1975BONN08055. NARA AAD, US State Department, Cable Document Number 1975BONN08055, https://aad.archives.gov/aad/createpdf?rid $=233918 \& d t=2476 \& d l=1345$

1975STATE052712. NARA AAD, US State Department, Cable Document Number 1975STATE052712, https://aad.archives.gov/aad/createpdf?rid $=202587 \& \mathrm{dt}=2476 \& \mathrm{dl}=1345$

1975USBERL02657. NARA AAD, US State Department, Cable Document Number 1975USBERL02657, https://aad.archives.gov/aad/createpdf?rid $=63501 \& \mathrm{dt}=2476 \& \mathrm{dl}=1345$

Allardt 1969. Akten zur Auswärtigen Politik der Bundesrepublik Deutschland, Botschafter Allardt, Moskau, an Bundesminister Brandt, Z B 6-1-10026/69 geheim, Aufgabe: 5. Januar 1969, 13.00 Uhr Fernschreiben Nr. 26 Ankunft: 5. Januar 1969, 12.45 Uhr, Gespräch zwischen Botschafter Allardt und Stellv. Sowjetischen Außenminister Semjonow und Botschafter Falin in Moskau. VS-Bd. 4434 (II A 4)].

Duckwitz 1969. Akten zur Auswärtigen Politik der Bundesrepublik Deutschland [Aufzeichnung des Staatssekretärs Suckwitz. St.S. 22/69 geheim 9. Januar 1969] „Abrassimov noted the Americans in West-Berlin were in the same situation like he was in the DDR. Nothing would happen in the DDR without approval of the Soviet Union, and he was in charge of making sure that the Soviet requests would be followed in the DDR. And this would be so in the future as well. ... Americans would bear great responsibility if they could not decide to prevent the hosting of the Bundesversammlung (for the election of the President of the Federal Republic of Germany) in West-Berlin."

Gehlhoff 1975. Runderlass des Staatssekretärs Gehlhoff vom 7. Februar 1975, 501-505.34, Dokument 22 in den Akten zur Auswärtigen Politik der Bundesrepublik Deutschland 1976.

Barzel 1976. Parlamentarische Anfrage von MdB Rainer Barzel CDU/CSU, Anlage 13 zur 248. Sitzung des Deutschen Bundestages, Stenographischer Bericht, Bonn, Freitag, den 4. Juni 1976

Allardt 1969a. Akten zur Auswärtigen Politik der Bundesrepublik Deutschland, Botschafter Allardt, Moskau, an Bundesminister Brandt, Z B 6-1-10026/69 geheim, Aufgabe: 5. Januar 1969, 13.00 Uhr Fernschreiben Nr. 26 Ankunft: 5. Januar 1969, 12.45 Uhr, Gespräch zwischen Botschafter Allardt und Stellv. Sowjetischen Außenminister Semjonow und Botschafter Falin in Moskau. VS-Bd. 4434 (II A 4)].

"Soviet Foreign Affairs Minister Semjonov remarked he personally had no particular high opinion on the press, including the West German one, in particular when it mas meddling into diplomatic affairs."

Moersch 1976. Antwort von Staatsminister Moersch auf die parlamentarische Anfrage des Abgeordneten Hösl CDU/CSU, Anlage 9 zur zur 248. Sitzung des Deutschen Bundestages, Stenographischer Bericht, Bonn, Freitag, den 4. Juni 1976. 
Springer, A. 1967. Axel Springer, 26 Oktober 1967, Viel Lärm um ein Zeitungshaus: „Richtlinien allerdings gibt es oder - besser gesagt - Pflöcke, die gesteckt sind, zwischen denen sich die journalistische Individualität und das fachliche Können unserer Redakteure, Reporter, Leitartikler und Korrespondenten auswirken können. Vier Grundsätze sind es: 1. Unbedingtes Eintreten für die Wiederherstellung der deutschen Einheit. ..."

"We have 4 principles: 1. Unconditional standing for the German reunification. ..."

Scheel 1970. Akten zur auswärtigen Politik der Bundesrepublik Deutschland. Gespräch des Bundesministers (Aussen) Scheel mit dem französischen Außenminister Schumann Z A 5-4.A/70 VS-vertraulich 16. Januar 1970] von Aussenminister Walter Scheel mit seinem französischen Amtskollegen Maurice Schumann, in der Scheel erklärte, „... sei die Bundesregierung fest entschlossen, in allen Fragen, die sich auf Berlin bezögen, in Bezug auf jedes Wort und jeden Satz, Fühlung mit den Verbündeten zu halten“".

Brandt, W. 1970. [vgl. BT Stenographische Berichte, Bd. 71, S. 842. Am 14. Januar 1970] von Bundeskanzler Willy Brandt, welche dieser zwei Tage vorher zum Bericht über die Lage der Nation im gespaltenen Deutschland abgegeben hatte: „Ich, meine Damen und Herren, habe lange genug in Berlin gewirkt, um zu wissen, daß es Dinge gibt, für die unsere Schultern zu schmal sind und für die uneingeschränkte Souveränität anzustreben die Bundesrepublik kein Interesse hat."

1976BONN03008. NARA AAD, US State Department, Cable Document Number Cable Mai 1975 „brüskiert“. 1976BONN03008 23Feb1976, https://aad.archives.gov/aad/createpdf?

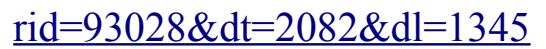

"1. There was an extensive discussion of the possible federal prosecution in Berlin of the Lorenz Kidnappers, with all three ambassadors expressing their unhappiness about public statements being made by federal prosecutor general Buback which were embarassing the allies and had the effect of weakening their legal position. Gehlhoff (Anmerkung vom Autor: Staatssekretät Gehlhoff hatte 1975 den vorgenannten Berlin-Erlass getätigt) conceded that Buback's statements were unfortunate and indicated that the foreign ministry would again raise with the ministry of justice and desirability of greater discretion on the part of the federal prosecutor general. He noted that the ministry of justice had already expressed the view to the foreign ministry that federal prosecution was probably unavoidable, but that the case would probably not come to trial this year. The foreign ministry had stressed the need for full consultation with the allies before final decisions were taken. Gehlhoff also said the German government considered it essential that the Soviet protest delivered in Berlin at POAD level on February 12 receive a formal allied reply, although acknowledging that the response given on the spot by the US POLAD had been a good one."

1976USBERL01017. NARA AAD, US State Department, Cable Document Number 1976USBERL01017. British say „,always difficult to control Buback“, 13 May 1976. https://aad.archives.gov/aad/createpdf?rid $=258180 \& \mathrm{dt}=2082 \& \mathrm{dl}=1345$

1975BONN03866. NARA AAD, US State Department, Cable Document Number 1975BONN03866. https://aad.archives.gov/aad/createpdf?rid $=203210 \& d t=2476 \& d l=1345$

On March 7, 1975 USBonn reports to USBerlin and DC: "FRG has provided allies with clarifying information but allies have expressed unhappiness over lack of prior consultation in what 
undoubtedly is a sensitive area. ... We have told FRG that public clarification of situation needed. ...Allied embassies learned March 6 via press reports that Generalbundesanwalt, Buback, had gone to Berlin March 5 and was inspiring publicity that he was in Berlin to direct investigation of Lorenz case. At Bonn Group meeting called to look into matter, allies expressed deep concern to FRG over publicity-seeking aspects of GBA's actions and over failure to consult in advance. Allied reps said that lack of consultation particularly regrettable in view of known Soviet sensitivites with respect to role of federal organs in Berlin, was was re-emphasized by Feb 27 protest in moscow regarding Bundesgerichtshof."

Justizminister Vogel habe auf eine öffentliche und klärende Erklärung seine Einwilligung geben müssen.

Mit Meldung vom 8. März (1975STATE052712) nach Bonn und USBerlin drückt das State Department seine Hoffnung aus, dass alle Bonner Regierungsstellen sich künftig in Sachen Berlin mit den Alliierten koordinieren.

Am gleichen Tag meldet Berlin nach Bonn (1975USBERL00449), dass die Alliierten unter französischem Vorsitz Erklärungen vom Senat zur Rolle Bubacks in Berlin erhalten haben. Der Senat habe versichert, dass er den Sachverhalt in der Öffentlichkeit im richtigen Lichte darstellen würde. Der (Berliner) Tagesspiegel habe die entsprechende Erklärung, dass die Ermittlungen zur Entführung von der Staatsanwaltschaft beim Berliner Landesgericht geführt würden, vollständig abgedruckt.

Lücking 1975. Akten zur Auswärtigen Politik der Bundesrepublik Deutschland. Wissenschaftliche Leiterin: Ilse Dorothee Pautsch. Ed. by Institut für Zeitgeschichte / Möller, Horst / Miard-Delacroix, Helene / Schöllgen, Gregor / Wirsching, Andreas. eISSN: 2192-2462

http://www.degruyter.com/view/product/213797

1976USBERL02003. NARA AAD, US State Department, Cable Document Number 1976USBERL02003.https://aad.archives.gov/aad/createpdf?rid $=343254 \& \mathrm{dt}=2082 \& \mathrm{dl}=1345$

1977BONN01925. NARA AAD, US State Department, Cable Document Number 1977BONN01925, https://aad.archives.gov/aad/createpdf?rid $=23765 \& \mathrm{dt}=2532 \& \mathrm{dl}=1629$

1976USBERL01631. NARA AAD, US State Department, Cable Document Number 1976USBERL01631, https://aad.archives.gov/aad/createpdf?rid $=55534 \& \mathrm{dt}=2082 \& \mathrm{dl}=1345$ vom 6. August 1976.

Subject: New Soviet warning against federal prosecution of Lorent kidnapers. 6. Aug. 1976 Tyutyunov at US Embassy: „We expect that the competent authorities of the three western powers, in accordance with their obligations under the quadripartite agreement, will take the appropriate measures to prevent the illegal involvement of the federal prosecutor general of the FRG in the planned court proceedings.“ End Statement.

Prinzing 1975. Theodor Prinzing, Erster Vorsitzender Richter des 2. Strafsenats des Oberlandesgerichts Stuttgart vom 4. Februar 1974 bis Januar 1977. Für diesen schwierigen Prozess ausgesucht worden war Prinzing, da er über „Erfahrungen in Monster-Prozessen, Durchblick, Durchsetzungsvermögen und erkennbaren Ehrgeiz“" verfüge. Die Welt, 17. Mai 1975, Seite 3.

Baader, A. 1975. Erklärung von Andreas Baader vor Gericht am 28. Oktober 1975, abgedruckt im Spiegel 28. Oktober 1975: Andreas Baader zur Isolationshaft. „Na ja. Aber wir machen das kurz. 
Ablehnung, das ist ja sowieso eine Lächerlichkeit bei diesem Senat ... man wird ihn in jedem Fall hier nicht loswerden. Aber dazu wollte ich einfach nur mal kurz feststellen: Wir sind sicher, Prinzing, dass Sie hier auch an Ihrem eigenen Urteil arbeiten.“

Griesbaum, R. 2011. Der Spiegel June 9, 2011.

http://www.spiegel.de/politik/deutschland/raf-prozess-der-general-muss-weg-a-767702.html

OLG 2012. Becker Prozess 2012. OLG Stuttgart, Urteil vom 06. Juli 2012, Az.6-2 StE 2/10.

Sattar, M. 2009. Der Spiegel, 27. November 2009. „Die schwarze Braut“. „Die Mörder Bubacks formieren sich im "Kommando Ulrike Meinhof."

Geiger, S. 2011. Stuttgarter Zeitung. „Der Zeuge taugt als Kronzeuge nur bedingt.“ RAF PeterJürgen Boock stützt die Anklage gegen Verena Becker nicht. February 4, 2011.

Preusker, H. 1992. Brennpunkt, ARD TV documentary, July 1, 1992. See also Harald Preusker, Leiter JVA Bruchsal, im Buch das RAF Phantom von G. Wisnewski, Seiten 231-232.

Schily, O. 1972. Beschluß des Zweiten Senats vom 14. Februar 1973 - 2 BvR 667/72 - in dem Verfahren über die Verfassungsbeschwerde des Rechtsanwalts Otto Schily gegen den Beschluß des Bundesgerichtshofs, 3 Strafsenat, vom 25 August 1972 - 1 BJs 6/72 / StB 18 u. 20/72 - sowie Antrag auf Erlaß einer einstweiligen Anordnung. BVerfGE 34, 293 (293).

Mengen, J. 1976. Die Zeit. „Kaum ein Zweifel an Müller“. July 23, 1976 - Stuttgart-Stammheim. Der „Kronzeuge“ bringt die BM-Anwälte in arge Bedrängnis. Müller said, all RAF members had been in the belief that defense lawyer Otto Schily had been the one who had smuggled the Ensslin message out of the prison, but Schily's name was in fact never mentioned. Schily was thus excluded from the court proceedings, but this decision was overturned later by the constitutional court.

Knobbe, M. 2007. Stern. April 27, 2007. Ehemaliger RAF-Helfer. Der Ankläger und sein Informant.

Speitel, V. 1980. Der Spiegel: „Wir wollten alles und gleichzeitig nichts“. Ex-Terrorist Volker Speitel über seine Erfahrungen in der westdeutschen Stadtguerilla, Nr. 31/1980, Nr.32/1980, 38.

Siedler, M. 2008. „Die RAF im Spiegel der Literatur und der westdeutschen Berichterstattung“ Diplomarbeit Philosophie, Wien 2008, Universität Wien.

Kerscher, H. 2010. Süddeutsche Zeitung, Mutmaßungen über ein verschwundenes RAF-Mitglied, May 17, 2010.

http://www.sueddeutsche.de/politik/terrorismus-mutmassungen-ueber-ein-verschwundenes-raf$\underline{\text { mitglied-1.206192 }}$

1977STUTTG00759_c. NARA AAD, US State Department, Cable Document Number 1977STUTTG00759_c https://aad.archives.gov/aad/createpdf?rid $=123146 \& \mathrm{dt}=2532 \& \mathrm{dl}=1629$

Benesch, A. 2012. Interview Alexander Benesch für infokrieg.tv with Michael Buback, 
https://www.youtube.com/watch?v=XCcBJrqjCK8, veröffentlicht am 14. Juli 2012 auf YouTube.

Köppchen, U. 2007. Deutschlandfunk, May 3, 2007. „Echo der Vergangenheit“. A surprising turn in a chapter of west Germany postwar history considered closed for a long time. "Wer erschoss Siegfried Buback?", titelt der "Spiegel", und der ehemalige Bundesinnenminister Gerhart Baum mutmaßt: "Der Eindruck drängt sich auf, dass hier Täter Vorwürfe auf sich genommen haben, die sie gar nicht verdienen, also der Folkerts war offenbar nicht dabei, ist aber dafür verurteilt worden. Und der Wisniewski war dabei, ist aber nicht verurteilt worden. Ich glaube, es gibt Anzeichen, dass das Schweigekartell aufbricht, also das gegenseitige Versprechen nichts zu offenbaren, dass das nicht mehr hält."

De Graaf, B. 2011. Evaluating Counterterrorism Performance: A Comparative Study, von Beatrice de Graaf, Routledge Chapman Hall, Milton Park and New York: Routledge, 2011. ISBN: 978-0415-59886-6.

KAS 1977. Konrad-Adenauer-Stiftung. CDU Dokumentation 34, Oktober 13, 1977.

CDU_Dokumentation_kas_25811-544-1-30.

http://www.kas.de/wf/doc/kas_25811-544-1-30.pdf?110826092413

Pautsch, I.D., Peter, M., Ploetz, M, Geiger, T. 2007. Akten zur Auswärtigen Politik der Bundesrepublik Deutschland. 1976. München 2007. ISBN: 978-3-486-58040-2

Ruete 1970. Aufzeichnung des Ministerialdirektors Ruete vom 6. Januar 1970, II A 5-82.00-94.14/70 VS-vertraulich, über sein Gespräch mit CDU/CSU Fraktionsvorsitzenden Dr. Rainer Barschel: „Eine Ostpolitik gegen die Opposition sei praktisch unmöglich.“

Schmidt, H. 1977. Gespräch des Bundeskanzlers Schmidt mit dem sowjetischen Botschafter Falin, October 26, 1977. Akten zur auswärtigen Politik der Bundesrepublik Deutschland, No. 2 (1977), p. 1458-1463.

1975BONN04346. NARA AAD, US State Department, Cable Document Number 1975BONN04346. "With two notable exceptions, we were satisfied with German-Allied contacts in Bonn on the case. Exceptions are, of course, Buback matter and Bundesgrenzschuetz (BGS) personnel in Berlin.“ https://aad.archives.gov/aad/createpdf?rid=206551\&dt=2476\&dl=1345

Rogalla, D. 1987. Sattelfest - Europa erfahren. Tagebuch: Aus Nordrhein-Westfalen per Fahrrad durch den Kontinent. N.P. Engel Verlag, Seite 72, 1987.

On July 24, 1986 vacation season started in NRW and a bomb exploded at a Fraunhofer Institut at thr RWTH Aachen polytechnical school. 18 days before Siemens manager Prof. Dr. Karl-Heinz Beckurts had been assassinated with a road-side bomb in Germany. German Bundesgrenzschutz had lonely ordered full checks at the border and ring alert, whereas other police had not ordered such measures. Rogalla explains how a "deep state" police attacks civil rights by ignoring government and citizens.

Komossa G.-H. 2014. Die deutsche Karte, Das verdeckte Spiel der geheimen Dienste, Ein Amtschef des MAD berichtet, ARES Verlag, 9. Auflage Graz 2014, SBN 978-3-902475-34-3, Seite 190.

Igel, R. 2006. Terrorjahre, Die dunkle Seite der CIA in Italien, F.A. Herbing Verlagsbuchhandlung 
GmbH, 2006. Ex Prime Minister Giulio Andreotti explains at court that Italy's military and intelligence service had not been under Italian control.

1977USBERL03045. NARA AAD, US State Department, Cable Document Number 1977USBERL03045. https://aad.archives.gov/aad/createpdf?rid=305922\&dt=2532\&dl=1629

Tams, C. 2007. Die Zuständigkeit des Bundes für die Abwehr terroristischer Gefahren, in: Die öffentliche Verwaltung 60 (2007), S. 367-375.

Kraushaar, W. 2006. Einleitung - Zur Topologie des RAF-Terrorismus, in „Die RAF un der linke Terrorismus“, Band 1, Seite 30. Hamburger Institut für Sozialforschung. 1. Auflage November 2006, ISBN-13 978-3-936- 096-65-1 (Bd. 1-2).

Mauz, G. 1977. Der Spiegel vom 24.01.1977. „Das kommt alles vom Rechtsanwalt Schily“. Zum Ausscheiden des Richters Prinzing in Stuttgart-Stammheim. http://www.spiegel.de/spiegel/print/d41001965.html

Kühnert, H. 1977. Zeit, February 4, 1977. Baader-Meinhof Prozess. Stammheim ohne Prinzing. Warum der Gerichtsvorsitzende gescheitert ist (Stammheim without Prinzing. Why the presiding judge has failed ). http://pdf.zeit.de/1977/06/stammheim-ohne-prinzing.pdf

Prinzing, T. 2007. Der Tagesspiegel. "Baader wäre als Soldat ganz brauchbar gewesen", October 14, 2007. "Journalists promoted a climate where people thought it would be justified to kill me. But they were also largely responsible for my worn down state of mind, which caused my resignation. Maybe they saved my life by doing so."

Lamprecht, R., Sternsdorff, H.-W. 1976. Spiegel, February 16,1976. „Der Rechtsstaat auf dem Hackklotz“. Interview with AG Siegfried Buback.

Prantl, H. 2010. Süddeutsche Zeitung, May 19, 2010. Mord an Buback. Ein "anständiger Mann" als Hassfigur.

Spiegel 1975. Der Spiegel, June 30, 1975. Baader-Anwalt Hans-Heinz Heldmann: "Und wieder schlug der Buback zu, da waren's nur noch vier."

Springer Wiki. http://de.wikipedia.org/wiki/Axel-Springer-Hochhaus

1977USBERL03045. NARA AAD, US State Department, Cable Document Number 1977USBERL03045

https://aad.archives.gov/aad/createpdf?rid $=305922 \& \mathrm{dt}=2532 \& \mathrm{dl}=1629$

1977STUTTG01728. NARA AAD, US State Department, Cable Document Number 1977STUTTG01728. https://aad.archives. gov/aad/createpdf?rid $=238643 \& \mathrm{dt}=2532 \& \mathrm{dl}=1629$

Kennedy, J.F. 1961. Address before the American Newspaper Publishers Association, „The President and the Press“, 27. April 1961. 
www.jfklibrary.org/Research/Research-Aids/JFK-Speeches/American-Newspaper-PublishersAssociation_19610427.aspx

1976USBERL02003. NARA AAD, US State Department, Cable Document Number 1976USBERL02003.https://aad.archives.gov/aad/createpdf?rid=343254\&dt=2082\&dl=1345 „, We are concerned, however, that matter has already received so much publicity and been so linked in public's eye to other allied restrictions on Federal Prosecutor's activity, notably of issuance of BK/O on anti-terrorism law, that this decision, if taken, would be attributed either to allied pressure or an allied refusal to consider ways in which an effective federal prosecution could occur. Allies could then come under increasing attack for taking allegedly more restrictive policy on FRG-Berlin ties in face of soviet pressure. "

Haas, M. 2000. BGH 3 StR 377/99 - Urteil v. 11. Februar 2000 (OLG Frankfurt/Main). Grenzen bei der Beweiswürdigung von anonymen Quellen; "In camera" - Verfahren im Strafprozeß nicht zulässig Gerichtsurteile gegen Monika Haas. Vgl. Monika Haas' Prozesserklärung 30. März 1998 http://www.socialhistoryportal.org/sites/default/files/raf/0019980330_0.pdf

Bolesch, C. 1991. "Profilierungskämpfe im Schatten des Krieges", in: Publizistik und Kunst 40 (1991), Nr. 2 (February 1991), S. $10-11$.

Buback M., 2012a. Brief von Michael Buback an den Spiegel: Nr. 28/2012, Das Urteil über Verena Becker. Schützende Hand?

Buback, M. 2012b. Schlussvortrag von Michael Buback in der Hauptverhandlung vor dem OLG Stuttgart gegen die Heilpraktikerin Verena Christiane Becker:

http://www.3sat.de/kulturzeit/pdf/Buback_Plaedoyer_140612.pdf

Hünniger, A.H. 2012. Die Welt, May 16, 2012. Ob sie aber über Oberammergau: Deutsches Theater: Auch der letzte Cliffhanger bringt den Prozess gegen Verena Becker keiner Auflösung näher“. http://www.welt.de/print/die welt/kultur/article106319868/Ob-sie-aber-ueberOberammergau.html

Dittrich, M., 2015. Deutschlandfunk, June 6, 2015. RAF-Terroristin Susanne Albrecht - Faustpfand für die Stasi. http://www.deutschlandfunk.de/raf-terroristin-susanne-albrecht-faustpfand-fuer-diestasi.724.de.html?dram:article id=321899.

Schäuble: "Nobody knew anything, what is being told today, that there had been assumptions at the $B N D$ or BKA, these are all lies in order to cover their own helplessness. Nobody thought the DDR secret service were capable of such criminal energy."

Michael Diestel, who for a short time of 6 months was DDR Minister of Interior prior to the German reunification: "I immediately drove to Bonn and met with Schäuble, who back then was the Federal Secretary of Interior. And I have to tell you, these secret service stories - they were to me disgusting, swinish, destructible."

Müller, G. 1979. Spiegel, May 14, 1979. RAF terrorist Gerhard Müller: "Heute diene ich mit der reinen Wahrheit". Gesetzwidrige Manipulationen mit "Kronzeugen" in Terroristenprozessen. (Spiegel: Kripo und Bundesanwaltschaft haben sich auf dunkle Geschäfte mit Terroristen eingelassen.) Gerhard Müller: "Today I am serving with the pure truth." Unlawful manipulations with cooperative witnesses in terrorist trials. 
1977STUTTG00651. NARA AAD, US State Department, Cable Document Number 1977STUTTG00651.

https://aad.archives.gov/aad/createpdf?rid $=85653 \& \mathrm{dt}=2532 \& \mathrm{dl}=1629$

"4. Prosecutor Wunder also referred to murder of federal attorney general Buback and two others saying Stuttgart trial should not be affected by anger stemming from murder. However, Wunder indirectly suggested imprisoned anarchists may be responsible for the Karlsruhe murders since it not yet known whether the Karlsruhe murders had acted ,faithful to the old orders "." 